\title{
Ethnic Politics and Nigerian Democracy: The Way Forward
}

\author{
Martins Ekunke Eniemeh, Prof. Sale Y. Ibrahim \\ University of Maiduguri, Department of Public Administration, Bama Road, Maiduguri, Borno State, Nigeria
}

\begin{abstract}
Ethnic politics in Nigeria's political system have come to be a tragic and constant in Nigeria's political system; where one must belong to the mainstream of ethnic politics for political relevance. Without any form of prejudice, it is a fact that Nigeria is a multi-ethnic state with differences in its socio-political and economic development all of which have resulted in conflicts and counter conflicts. It depicts attachments to the sub-national ethnic groups which threaten to undermine national integration and therefore divide the nation. Significantly, ethnicity in Nigeria was orchestrated by a long period of colonialism, a period which witnessed the ascendancy of the three major ethnic groups in Nigeria to the socio-political domination of other ethnic groups. It was a period when the three major ethnic groups were used by the colonialist as a pedestal for the distribution of socio-political and economic goods. Using a mixed method, this work argues that Nigeria's political problem hinges on the negative consequences of ethnic politics. The paper concludes that if Nigeria's political system must progress, it must be anchored on the need for the review of the constitutional and political structure of Nigeria to restore healthy political competition as opposed to the existing outdated political mechanism imposed on Nigeria by the military under the 1999 Constitution of the Federal Republic of Nigeria.
\end{abstract}

Keywords: Ethnic politics, Democracy, Nationalism, Ethnic loyalty.

\section{INTRODUCTION}

$\mathrm{T}$ he phrase "ethnic politics" refers to a situation in which politicians tend to mobilize support on the basis of an appeal to ethnic identity and people tend to support leaders from the same ethnic group. Ethnic politics is often regarded as a problem when different groups come to see each other as competitors for power and when members believe that they will be excluded from the benefits of state assistance and protection if "one of their own" is not in power. The reason is that such politics often promotes interethnic tension and violence, leading many to argue that ethnic politics needs to be eradicated or managed through tailored institutional arrangements.

If you are born in Nigeria, grow up and trained to become an engineer, lawyer, doctor or a teacher and probably die rich; you remain a Nigerian. But within the context of ethnicity; as long as you remain a Nigerian your political affiliation notwithstanding, your ethnic group is fixed. To Chandra (2012) everyone belongs to one ethnic group, the membership of each group remains for a long period of time, and as it is passed down from generation to generation, along the line there may be war, economic crisis but the fact is ethnic groups does not change. Without the consent and consensus of different tribes/ethnic groups which were over 300, the Nigeria federation was constituted by the British colonialist in the amalgamation of 1914. This action was reinforced by Onwe (2019) that on the formation of Nigeria on January 1, 1914, all the ethnic nationalities were conquered, subdued and placed as the subjects of the British Monarch. This forced/artificial marriage of ethnic groups which emerged upon the British imperial expansion no doubt has significant consequences for political development in Nigeria (Brown, 2013). This anomaly impelled the political leaders to start agitating for de-amalgamation of Nigeria in a bid to forestall the future danger which the forced merger of hitherto independent ethnics groups portended. Significantly, this fundamental error has deepened in contemporary Nigeria, hence the conspicuous differences in Nigeria's ethnic configuration stretching from language to population, geographical landscape, level of education which the colonialist never considered before the artificial creation of Nigeria.

To this end, late Ahmadu Bello in 1944 described the amalgamation of Nigeria as the mistake of 1914 which if allowed to remains will ultimately lead to unstoppable bloodshed and failed country. Lending his voice to Ahmadu Bello's observation, late Obafemi Awolowo described Nigeria as a mere geographical expression (Brown, 2013) that is not qualified to be called a country not alone a nation and if the amalgamation could not be reversed, then Nigeria should be restructured as strictly a federal state to give room for every ethnic group to enjoy freedom from being dominated by any one single tribe. Contrary to the expected unity, the politics of administration in Nigeria has been offensively punctuated by very disturbing ethnic politics. Brown (2013:172) expound that in Nigeria's political system, the reconfiguration, formation of political parties, distribution of human and material resources and even crises (coups, civil war, and religious impasse) are hinged on ethno-religious politics. Without any form of prejudice, it is a fact that Nigeria is a multi-ethnic state with differences in its socio-political and economic development all of which have resulted into conflicts and counter conflicts. Notwithstanding the era of globalisation, the level of ethnicity in Nigeria has unabatedly increased. Obviously, this is as a result of the life style of various ethnic groups which revolves round their ethnic identity; hence, the difficulty in producing uniformly informed socio-political and economic policies. 
It is against this background that many socio-political and economic problems tied to ethnicity still flourish in the polity, originating from the political rivalry amongst ethnic groups seeking for political relevance cum power and the wealth that comes with it. Ethnic politics have been a recurrent if not a permanent phenomenon in Nigeria's political system. Ethnicity is, therefore, at the centre of politics; it is either you belong to the mainstream of ethnic politics or not without which one may not likely be politically relevant. In essence, it is not the political party that matter but your ethnic group. Nigeria no doubt is a highly divided society with three major ethnic groups (Yoruba, Igbo and Hausa/Fulani). The political system in Nigeria has since been tailored along these ethnic lines. This, however, does not mean there are no other ethnic groups in Nigeria. Of recent is the use of North/South dichotomy-a political arrangement that states that if the Hausa/Fulani from the north produces the president in a particular political dispensation, the next will have to come from the southern Yoruba and Igbo. However, this arrangement (not in Nigeria's constitution) did not specify which part of the south thus pitching the majority ethnic groups in the south against the minority ethnic groups in the zone. This informs every socio-political and economic policy responses to the challenges posed by ethnic differences in the country which include among other power-sharing system, quotas system in the educational sector ect.

\section{THEORETICAL FRAMEWORK}

According to Encarta (2004) a "theory" is an idea or belief about something arrived at through assumption and in some cases a set of fact, propositions, or principles analysed in their relation to one another and used, especially in science, to explain phenomena ( cited in Best,2006). To Enwere (2015), theory is a set of hypothesis postulating the relationship between variables or conditions advanced to describe, explain and predict phenomena and make prescriptions about how positive change ought to be engineered, as such psycho cultural conflict theory is applied to this study as stated below.

\section{Psycho - Cultural Conflict Theory}

The theory psycho- cultural conflict emphasises the role of culturally induced conflict; it shows how enemy images are created from deep - seated attitudes about human action that are learned from early stage of growth in explanation of conflicts (Ross, 1993). Ademola (2006) contends that even though there are different forms of identities, the one that is based on people's ethnic origin and culture that is learned on the basis of that ethnic origin is one of the most important ways of explaining violent conflict. Identity is thus seen to be the reason for social conflicts that take long to resolve. Enwere (2015) on the other hand buttressed that the inability of racial groups to recognise and identify differences in culture leads to irrational and unfounded hatred, fear and mistrust provoking feelings of dislike and harm especially of one particular religion or ethnicity against another. The holding of such performed opinions based on irrational feelings or inaccurate stereotypes is the key source of most violent religious and ethnic conflict.

Psycho- cultural conflict theorist argue that social conflicts that take long to resolve become possibility when some groups are discriminated against or deprived of satisfaction of their basic (material) and psychological (non-material) needs on the basis of their identity . these needs are identified in Maslow's theory of 'Motivation' (1970) and Burton's (1990) 'Human Needs' theory; both of which describe the process by which individual or group seeks to satisfy a range of needs moving from the basic ones such as food and sex to the highest needs that they described as 'self - actualization'- the fulfilment of one's greatest human potential (Ademola, 2006).

Crighton (1991) urges that the existence of the long history of humiliation, oppression, victimization, feelings of inferiority or superiority and memories of past persecution which erodes a person's dignity, racial identity and self-esteem usually lead people to resort to vengeance, thereby escalating the pathological dimension of conflict (Enwere, 2015).

MacLean (1975) in his work 'on the evolution of three mentalities' followed the same path with Spinoza's line of thinking in saying that under the anxiety of threatened attack or actual denial of basic needs, the probability that people will react violently is increased. Ademola (2006) maintained to the view of conflict that are caused by crisis of identity are usually the most dangerous and most violent. Identity is an unshakable sense of self-worth, which makes life meaningful and includes the feeling that one is physically, socially, psychologically, and spiritually safe.

Northrup (1989) views identity as a psychological sense of self as well as self as it relates to the world. Self - definition takes place on different levels: interpersonal, community, organizational, cultural or international. However, events which threaten to remove the feelings of 'safety' that are tied to different forms of identity usually lead to defensive reactions aimed at avoiding such spiritual or physical exposures. Identity operates in this way not only in relations to conflict between people, but also in situations of conflict between groups.

As observed by Lake and Rothschild (1996) actors form beliefs in a subjective way that draws mainly on the experiences of past interactions with others. The fear that individuals and groups experience force them to see threats whether real or imagined, and to suspect the motive of others around them. The tendency to see things in a selective way is mostly due to a past history of competition for scarce resources in which the opposition always comes out as a winners. Therefore, the psycho- cultural conflict theory imply that conflict is a product of a crisis of identity and the struggle for racial, cultural and value domination (Enwere 2015).

Going from the above it could be concluded that human being tend to be violence when both basic (materials) and psychological (non- materials) needs are deprived based on 
their identity. Thus, ethnicity is basically nothing but psych originated from culture in which human being learnt to behave in certain way.

\section{REVIEW OF LITERATURE}

Ethnicity and ethnic politics in African society (IES) have become so imperative thus making the question of ethnicity to be one of the most topical issues of study by social scientist owing to the fact that it is debatably, one of the factors responsible for the continent's socio-economic and political difficulties. Scholars such as Easterly and Levine (1997), Posner (2004), Buhaug (2006), Easterly (2001), Barr and Oduro (2002) Milanovic (2003), Miguel and Gugerty (2005) and Kimenyi (2006) has argued that Africa's ethnic diversity remained an impeccable factor responsible for its low socioeconomic growth, political instability and conflict, high inequality amongst the populace and low or lack of service delivery - public goods. Berman (1998); Blanton, Mason, and Athow (2001) opines that the colonial period had a profound and debilitating effect on ethnicity in Africa, for a variety of reasons. It's been suggested that colonialists directly promoted ethnic diversity through divide and rule (costsaving) tactics thus promoting ethnic differences (Laitin, 1994). During the colonial era, ethnicity was rooted in the alliances of the indigenous uneducated leaders, integrating a well-defined ethnically governmental system where the local population was involved in the bureaucratic authoritarianism by incorporating them into the pre-colonial patron-client relations (Berman, 1998).

Hence the assumption that the constructivist modern processes of economic and political development have overwhelmingly moulded ethnic identities in Africa. In the post-colonial period most African states have done very little to promote nationbuilding and ethnic harmonisation, but rather focusing on superficial policies alongside the promotion of deep ethnic divisions that contributed to pervasive patron-client relations and by extension to political and economic instability (Green, 2011). The controversies around ethnicity seem to have been heated up by the high visibility of mobilized and politicized ethnic groups in most multi-ethnic states. Therefore, the extent to which ethnic nationalities are able to effectively manage the interplay of ethnic difference determines to what extent a multi-ethnic nation develops without a crisis (Adetiba, 2013). Snodgrass (1995) argues that multi-ethnic developing states are often faced with the challenges of achieving sustainable economic development coupled with the task of managing often volatile inter-ethnic relations. He further argued that many of such states are besieged by lingering underdevelopment and political conflicts.

They are under-represented among the fastest growing economies of the world, and are over-represented among low income or slow-growing economies, apart from featuring prominently on the list of countries that have suffered from civil war and [on going] insurgencies. This was the case in Nigeria. Significantly, ethnicity in Nigeria was orchestrated by a long period of colonialism, a period which witnessed the ascendancy of the three major ethnic groups (Yoruba, Igbo and Hausa/Fulani) to the socio-political domination of other ethnic groups. It was a period when these three major ethnic groups were used by the colonialist as a pedestal for the distribution of socio-political and economic goods. This has continued to impact negatively on the forces of national integration and cohesion in ethnically divided Nigeria to date. This legacy of pervasive patron-client relations and a complex ethnic dialectic of assimilation, fragmentation and competition have persisted in post-colonial Nigerian society, a phenomenon that has since remained fundamental.

If not central in Nigeria's political governance, thus accounting for the personalistic, materialistic and opportunistic character of Nigeria's politics; undermining its socio-economic and political transformation (Berman 1998). Hence the favor enjoys by a particular ethnic group when political leaders from co-ethnic group control political power when deciding with whom to ally and to whom to distribute public goods (Wimmer, et al., 2009). Ethnicity has therefore provided individuals and groups with their most important political resource in the competition for the scarce goods of modernity, as well as for access to local resources. What the above portends to mean is that in a plural society like Nigeria political activities tend to be organized along ethnic lines no matter how "national" the political parties in the country seems to be. Hence, the assumption of the diversity-breedsconflict school that demographic index of heterogeneity is likely to overlook how ethnicity relates to the state (Wimmer, et al., 2009: 317) while endangering national integration as well as inclusive development, where national integration is conceived as a process that unites people with different culture and social background into a national unit. In essence, a recognised national identity is significant to overcoming the dynamics of problems created by ethnic politics.

The main thrust of national integration which in the long run leads to development is to create room for unity among various groups and subsequently transform them into a political community (Shakir, 1982). However, national integration has remained an evolving pursue in the postcolonial ethnically divided Nigeria, although various methods and strategies of national integration such as Federal Character, Quota system, Zoning Formula, Oil producing and Non-oil producing states dichotomy have been opted for; but for the complexity and politicization of ethnicity, the problem has remained unabated. Achieving a sustainable national integration has, therefore, become a challenge for Nigeria owing to the contradictory socio-political strand of Nigeria where most ethnic groups, often, pursue their socio-political and economic interests using the ethnic currency. The problematic nature of ethnicity in Nigeria as conceived above can be explained within the framework of some theoretical points. According to Salawu \& Hassan (2011:29) the negative aspect of ethnicity in Nigeria hinges on the framework that while developed countries are characterised by the pattern 
variables of universalism, achievement orientation and functional specificity, the under-developed ones are characterized by particularism, ascription and functional diffuseness.

In essence, for the underdeveloped countries to move forward, they must adopt the pattern variables that orientate people to be more mindful of their national identity rather than an ethnic group. Empirically, the modern society like the United States and Britain presents a very good example, where groups with different backgrounds see themselves as an American with the same identity and sharing equally democratic rights. People with different origin like Italian, Spanish, Malaysian, Canadian, Chinese, Indian and South African etc. have also developed such identity notwithstanding their association with their original ethnic group. Debatably, ethnicity in Nigeria from the context of conflict theory; is a struggle over claims to socio-political and economic status in which the aims of the different parties are not only to gain appropriate political and economic values but also to disengage, or even destroy their rivals (other ethnic groups). This implies that conflict may not likely occur if different groups can accept one another, contrariwise conflict will undeniably lead to violence if different groups are not accepted and accommodated. This is the reason why one would agree with Nnoli (1978) that conflict is an important aspect of ethnicism. It is unavoidable under environments of the inter-ethnic struggle for scarce socio-political and economic resources; hence its negative impacts on Nigeria's political system.

\section{Ethnic Politics in Nigeria}

In Sub-Saharan Africa; the high level of ethnic diversity can be used to explain the region's poor socio-economic and political performance. Easterly and Levine (1997) explained that in a comprehensive cross-section of African states (Nigeria inclusive) ethnic assortment was associated with bad economic policies on the part of political leaders, slow economic growth and low levels of per capita income coupled with internal disharmony and instability that underpin the pluralistic framework of African society. Observably, ethnically divided countries always have a poor quality of governance, insufficient provision of socio-political and economic goods and frequent socio-religious and political crisis hinged on the promotion of ethnic agenda by political leaders instead of promoting policies that drives the process of nation-building. Nigeria, today, is one of the countries ranked low in indexes such as health care delivery, poverty alleviation, capacity building, educational standard, and generally infrastructural development. One major reason for this is as a result of the entrenchment of ethnic politics anchored by various political leaders. In Nigeria, ethnic politicking is a leading set of justifications for the poor economic performance of the polity.

Ethnic diversity according to Frank and Rainer (2012), often leads to rent-seeking by different ethnic groups thus generating conflict over provisioning of public goods. The constant domination of Nigeria's national life by the HausaFulani from the north, the Igbo from the south-east and Yoruba from the south-west, and subsequent ideological conflicts among political leader of these ethnic groups, consequentially, is a threat to the country's socio-economic development and by extension national security and peaceful co-existence. In ethnically heterogeneous societies like Nigeria, it is a common feature for the ethnic groups that produces the leader (head of state/president) to approach developmental policies that commandeer the ethnic losers and limit the production of public goods as well as representation in government to deprive those outside the ruling group of the benefit of getting stronger, most importantly within the realm of economic relevance. Therefore, amongst the numerous challenges to socio-political and economic development in Nigeria, is ethnic politics. In Nigeria, there are four closely related and visible levels of ethnic politics; inter-group, intragroup, ethnic-state and individual (Osaghae, 2003:60). Overtly, these levels operated the same political but present different socio-political and economic dynamics and issues.

At the individual level, for example, individual actors invoke the ethnic card at every slightest opportunity while pursuing in actual fact personal and private goals and most importantly ethnic goals. Contrary to what has been popularized by scholars of ethnicity; debatably, ethnicity is not a sociopolitical and economic resource only for the élites and the non-élites are not the passive political specimen of ethnic chauvinism (Osaghae, 2003). Recently, in uMlathuze area of Kwazulu-Natal; South Africa, the Igbo descent who are members of the Association of Nigerian Resident Union (ANRU) in uMlathuze district1 who thought they are being deprived of certain privileges decided to form a parallel ethnic association (Nzuko Ndigbo) to optimize the utility of ethnic connections. Fundamentally, the existentiality of ethnic politics in Nigeria was as a result of the denial of its citizens the various social-economic and political desires, identity, self-rule, security and equality, which is the basis of an egalitarian society and compounded by the protagonists of autocracy (the various military governments). Debatably, the instrument of ethnicity has been used by the political elites as an exclusion mechanism, in hand of the dominant ethnic groups using it to redistribute socio-political and economic resources toward their own member.

It can also be interpreted as a philosophy which individuals employ to resolve the uncertainties arising from the power structure within which they are located. A change in the ethnic group in power, therefore, translates to a change in sociopolitical and economic policies across the groups as well as a change in the distribution of political goods; hence, the low accountability of political leaders. The Buhari led administration for example, is said to have pandered to ethnoregional sentiments and hence his hard-line opposition to any form of restructuring, to please his support base. Therefore, his elevation of sectionalism to a near state policy has compromised national security on the slaughter slab of 
ethnoreligious sentiments, which has left marauding Fulani killer herdsmen with the freedom to destroy lives and property across Nigeria. Borrowing from Hashmi and Majeed (2015:319) the failure of states to engage a pluralistic framework that includes constitutional designs where the protection of ethnic identity is guaranteed leads towards a conflictual situation in which one ethnic group feel insecure against the dominance of others thus driving the feelings of antipathy which in the long run force ethnic groups to pursue their demands.

Politics and ethnicity in Nigeria are like identical twins; very difficult to separate a situation that have led the collapse of the traditional authority structures, state's managerial institutions with its products as factional rivalries amongst political elites and non-political elites within (the majority) and without (the minority) ethnic groups as well as regional socio-economic disparities. Very important to the discourse on ethnic politics in Nigeria is the question of how all ethnic nationalities (Hausa, Yoruba and Igbo) defined and interpreted their own history; particularly before and after the colonial period? Nigeria no doubt is a multicultural society and ethnicity is believed to be at the core of this multiculturalism. Otite (2002) argued that ethnicity is sustained openly or secretly by strong changes of the several coexisting ethnic systems of symbols. Prior to Nigeria's independence in 1960, the colonialists employed the instrument of ethnicity as a central administrative strategy in the administration of Nigeria. This was done under the disguise that Nigerians were still been ruled by their own people using the policy of "Indirect Rule", a cost-saving system.

Olawale (2018) noted that one of the notable features of Richard constitution of 1946 was its emphasis on the promotion of regionalism as a possible means of achieving political cohesion. Notwithstanding the amalgamation of 1914, the British continued to run the country (north and south) as separate political and administrative entities with little or no common linkage apart from the common economic infrastructure such as roads, railways and a common currency observed Mustapha (2006). It is therefore perceived that ethnic politics in Nigeria is a deliberate and inflexibly sustained phenomenon by the British colonialist making it the only institution through which ethnic groups could find a meaning to their lives. Ethnic politics in Nigeria can also be explained from the perspective of how ethnic groups perceive or see themselves after independence till date. Have they been able to realise their dreams? How would they affect changes to the political system to suit their aspirations within the polity? What are the strategies to achieve their goals? All these puts together have slackened sustainable socio-political and economic development in the polity, thus forcing Nigerians to put preference on what they can achieve as a member of a particular ethnic group instead of harnessing these differences for stability and sustainability of the polity.

Thus justifying the statement that ethnicity is one of the several identity-based connections that group and individuals often invoke to get what they want (Osaghae, 2003:61). It is therefore easy to believe that Nigeria as a nation is yet to effectively transit from a state of mutual distrust to a country of shared national ideals. This translates to mean that the more the strength of ethnic groups and their cohesiveness, the more the deterioration of nationalistic consciousness in every individual that makes the polity; thus truncating the development of national selfhood as well as political integration that engenders strong political system. In principle, ethnicity functions as an ideology whose focus and political implications are crucially influenced by the character of the individual which can be strengthened overtly or covertly by the state. In a study by Sriskandarajah (2005), it was discovered that the multi-ethnic states of Malaysia, Mauritius and Trinidad have been successful in achieving development and avoiding disharmony largely due to the pursuit of a hegemonic one nation strategy in the early decades following independence. Strategically, these countries lay emphasis on partnership between the major constituent ethnic groups and negotiated economic redistribution. Consequently, they were able to checkmate inter-ethnic inequality which is lacking in Nigeria polity within the light of state's influence upon power structure.

\section{Impacts of Ethnic Politics on Nigeria Political System}

Nigeria like the U S A, India and Brazil are a federation of 36 states with Abuja as the Federal Capital Territory (FCT). Nigeria's federation arguably is the brainchild of the British colonialist dictated by the state of her multiculturalist. Nigeria, as it is today, has 774 Local Government Area. In 1979 Nigeria adopted the United States presidential system to replace the British parliamentary system, with three arms of government (executive, legislature and judiciary) providing an institutional livelihood for supposed inclusive growth and development of the country through the instrument of checks and balances and separation of powers. Good as it would have been to harness the instrument of its diversity for growth and development, ethnicity and ethnic consciousness of the people would not. In Nigeria, ethnic politics are at some level an indication of [political] immaturity; as it makes an appeal to citizens in a democratic society on public policies very difficult, thus making such policies to be canvassed solely on the basis of ethnic groups. Such politics most often prevails when the most immediate socio-political and economic needs have not been met. This has always been the case in most developing countries. Ethnic politics is a political activity, through which different ethnic groups make, preserve and modify the general rules under which they live.

As such, politics is fundamentally, a social activity, tortuously linked, on the one hand, to the reality of diversity and conflict, and on the other to preparedness to co-operate and supportive. It is practically common to say that in a country with the stable political system there is bound to be a stable and progressive socio-political and economic development but where the system is fraught and heated up with ethnic politics what suffers is the developmental process. Obviously, one of 
the factors that have affected Nigeria's political development cum its image after the demise of colonialism is ethnic politics. The question of who will be the leader, which ethnic group will produce the leader, whose interest is he/she going to serve and many more have always been the bane of Nigeria's political system. It is a common knowledge that the mode of governance in which Nigeria achieved her political independence, was civil democracy; but with the systemic institutionalization of ethnicity, democratic governance has always been at the mercy of ethnicism. By implication, ethnic politics is anti-democracy as it depicts attachments to the subnational ethnic groups which threaten to undermine national integration and therefore divide the nation. Nigeria since her political independence in 1960 till date has experimented three distinct republican governments - 1960-1965, 19791983, 1999 till date - at times interrupted by a long period of military interregnum.

A quick survey of the political scenario in Nigeria after independence will show the magnitude to which ethnic allegiance has affected the nation's dream of having sustainable democratic governance that engenders sociopolitical and economic development. If Nigeria must progress on her developmental journey; it is required that Nigeria has to develop political strategies based on structural and perceptual perspective. By structural, it must involve political reforms at all level. From a perceptual perspective, it includes the elimination of misunderstanding brought about in the society in the name of ethnic politics. This, however, could be done when there are trust and close interaction with the contending parties; the ethnic groups and the state authority. Meaning that; ethnic politics is significant to explain the prevalence of decay in Nigeria's political development; a problem that can be solved constitutionally while avoiding its lingering effects. At independence, Nigeria had a federal structure made up of three regions; the Northern Region, Eastern Region and the Western Region. However, the MidWestern Region was carved out of the old Western Region in 1963, though with its own political manoeuvres. According to Adejuyigbe (1973), the general feeling in the Western Region was that the Federal Government led by a northerner did not respond.

To the demand of both the Eastern and the Northern regions' minority demand for states rather both Eastern and Northern regional governments opposed it and the Federal Government never see anything wrong in it. Interpreting this would mean that the creation of the Mid-Western Region was done to reduce the power and the influence of Western Region in the parliament to the advantage of the Northern region. The differences among the three regions that made Nigeria, however, became clear with the emergence of three powerful; regionally-based and ethnically sustained political parties (The Northern People's Congress, National Convention of Nigeria Citizens and Action Group). The Northern People's Congress (NPC) basically representing Hausa/Fulani interest was led by Sir Ahmadu Bello, the National Convention of
Nigeria Citizens (NCNC) dominated by the Igbo extraction was led by Dr Nnamdi Azikwe and the Action Group (AG) representing the interest of the Yoruba was led by Chief Obafemi Awolowo. Against this backdrop, one would say the foundation of ethnic politics that is rocking the boat Nigeria's political system today, was unwittingly constructed in the early years of Nigeria's polity.

It was believed that the defunct SDP enjoy more support from the Southern Regional states while NRC was more inclined to and enjoy more supports from mostly the states in the north. In the current democratic dispensation, the introduction of a rotational arrangement of the presidency by the Peoples' Democratic Party has made the office of the presidency a north/south affair. This, however, has not taken away ethnic voting patterns/sentiments from Nigeria political system. For example, Buhari, a "northerner" in the general election of 2015 won in almost all the states (Kano, Kaduna, Katsina, Kebbi, Zamfara, Sokoto, Adamawa, Gombe, Yobe, Bornu, Niger, Kwara, Jigawa and Kogi) in the north (the same in 2019 general election); his stronghold showing the magnitude of the damage ethnicity has cause to Nigeria. Therefore, ethnic consideration in Nigeria polity is seen as more important than who a leader is and what such a leader can do to promote unity and stability. Other national elective offices involved in the rotational formula include that of Vice President, Senate President and Deputy Senate President, Speaker and Deputy Speaker of the House of Representatives. However, each of these political offices is manned by an elected individual from one of the six geo-political zones and none of the regions concurrently enjoy two of the offices. However, as it's in Nigeria's political environment, this system arguably may likely be a short-term remedy for the problem of ethnicism in the absence of good governance that engender a sustainable political system and by extension socio-political and economic development.

Table 1: Six Geopolitical Zones in Nigeria

\begin{tabular}{|c|c|c|}
\hline $\begin{array}{c}\text { S } \\
\text { N }\end{array}$ & $\begin{array}{c}\text { Geopolitical } \\
\text { zones }\end{array}$ & States in the Geopolitical Zone \\
\hline 1 & North Central & Benue, Kogi, Kwara, Nasarawa, Niger, Plateau \\
\hline 2 & North East & $\begin{array}{c}\text { Adamawa, Bauchi, Borno, Gombe, Taraba and } \\
\text { Yobe }\end{array}$ \\
\hline 3 & North West & $\begin{array}{c}\text { Jigawa, Kaduna, Kano, Katsina, Kebbi, Sokoto } \\
\text { and Zamfara }\end{array}$ \\
\hline 4 & South East & Abia, Anambra, Ebonyi, Enugu and Imo \\
\hline 5 & South-South & $\begin{array}{c}\text { Akwa Ibom, Cross River, Bayelsa, Rivers, Delta } \\
\text { and Edo }\end{array}$ \\
\hline 6 & South West & Ekiti, Lagos, Ogun, Ondo, Osun and Oyo \\
\hline
\end{tabular}

Source: Naija Home based https://www.naijahomebased.com/geopoliticalzones-nigeria/

Ethnicity in Nigeria polity as it is today has become more persistent at every level. Conceivably, it has become the most potent political instrument for pursuing individual and group interests. Among the resultant negative effect of ethnic politics in Nigeria according to Babangida (2002) are wastage of human and material resources in ethnically stimulated crisis 
and communal clashes reinforcing the insubstantiality of the economy and political progression, threat to security of life and obviously property which has in no measure affected local and foreign investments and loss of confidence in the economy; increasing gaps in social relations among ethnic nationalities, structural suspicions and detestation for one another. This conflictual nature of Nigeria no doubt stems from its inter-ethnic struggle for political power and socioeconomic resources; which has often been characterised by inter-ethnic discrimination in the distribution of political offices. A good example is the minister for Federal Capital Territory (FCT) which seems to have been exclusively reserved for a northerner, the first and the only southerner who has ever occupied the office was Mobolaji AjoseAdeogun (1976-1979). The prevalence of ethnic politics in Nigeria may also be attributed to the failure of the Nigerian political system to contain the means through which various ethnic groups fight for economic and political power among them. Debatably, one of the factors that have contributed to this is the long and politically devastating period of military rule (1965-1979, 1983-1999); when Nigeria was run by the military as a quasi-federal system, in which the dreams and aspirations of the various ethnic groups have been overlooked. This is reinforced by the ruling Nigerian national elites who are ethnically stratified. Their aspirations for political power is not based on a compromise or sharing of values and thus disapprove of the demand for openness among various ethnic groups that constitute Nigeria, fair competition, local autonomy, and responsibility. In a pluralistic state such as Nigeria, these are values that are unconditionally necessary to provide a level playing ground for every ethnic group. Using the words of Brown (1994), can Adam Smith's unseen [economic] hands be replicated in Nigeria's multi-ethnic nature? In Nigeria, the political hands are too visible and powerful and tend to give some ethnic groups excessive political and economic advantage over others (the above table showing geopolitical zones in Nigeria put the three zones from the north at a better position to commandeer political resources/positions).

In the circumstances like this; political tension has always been the order of the day, hence the introduction of the principle of federal character in employment in the public sector which is intended to ensure fairness in the public sector. Significantly the employment and manipulation of ethnic loyalties by politicians in order to boost their chance of winning at the polls has fundamentally set one ethnic group against another with inestimable costs. This was identified by Osadolor (1998) that the structural disproportion of Nigeria's federal framework is the most potent source of the fear of domination among various groups. What this translates to mean is that various ethnic groups believe that as long as "their son/daughter" is the leader; they are secured with regards to the distribution of socio-economic and political resources. This fear encourages competitive federalism, which strengthened the politics of winner takes all. It, therefore, means that unless this fear is removed, ethnic politics will continue to be a challenge to Nigeria's political system.

Although going by the literature reviewed many scholar have talk about the problems and challenges of ethnic politics to democracy but none have extensively discussed on the effect and importance of ethnic considerations are of paramount in the politics of Nigeria. It has play profound role in areas of politics. Ethnicity cannot be dispose of politic. Fundamentally Nigeria history is an indication of ethnic supremacy remains focal point of every daily life activity. Therefore this paper intends to fill this gap in literature on the effect of ethnic politics on the Nigerian democracy and its way forward.

\section{RESEARCH METHODOLOGY}

\section{Study Area}

Nigeria most populous African nation and one of the world's most diverse countries covers an area of 923,768 sq. $\mathrm{km}$. on the shores of the Gulf of Guinea. To its West side is Benin Republic, Niger on the North, Chad to the North-East, Cameroon to the East and South-East. Nigeria came under the British imperialist during the $19^{\text {th }}$ century and with the 1 st January, 1914 amalgamation of Southern and Northern Protectorate the foundation of a nation now called Nigeria was laid.

The amalgamation which was brought about for administrative convenience was followed by protests from different peoples who were forced to live together without taking into consideration their differences in languages, culture, belief and tradition. Among different nations that were fused together incongruously were the Kanuri, Hausa, Fulani, Efik, Igala, Tiv, Jukun, Nupe, Yoruba, Edo, Ibibio, and Ijaw. As a result, Nigeria is populated by over 300 ethnic groups, (Okotoni, 2006), out of which Hausa/Fulani, Yoruba and Igbo were predominant.

The Hausa/Fulani, Yoruba and Igbo thus established their dominion in the Northern, Southern and Eastern regions of Nigeria respectively. At Independence in 1960, these three groups dominance in their regions led to minority ethnic groups' agitation for the creation of more states with the intention of weakening the dominant posture of Hausa/Fulani, Yoruba and Igbo (Ekpo, 2010). To this extent, the country which had only three regions at independence in 1960 has now metamorphosed into thirty-six States and separate Federal Capital Territory by October 1996.

Despite the breaking down of Nigeria into 36 States with FCT, the politics being practiced in Nigeria is that of politics of ethnicity, gang-up politics and political party with ethnic affiliation. The incessant struggle for power among these diverse ethnic groups is having far reaching impact on the corporate existence of the nation, vis a vis the attendant conflicts and insecurity which is daily shaking the feet of the nation. It is against this background that the study examines the complex nature of Nigeria in the area of ethnicity and 
ethnic politics/gang-up and effects of this type of politics on the political development of the nation.

\section{Research Design}

Research designs are approaches of carrying out research studies in order to achieve the objective of the research studies (Ihenacho, 2004). Scholars such as Kothari (2002) define research design as the arrangement of conditions for collection and analysis of data in a manner that aims to combine relevance to the research purpose with economy in procedure. Research design adopted for this study is survey research method. The researcher adopted the survey research design which is also classified as part of non-experimental research design. Our quantitative data was generated via questionnaire as instrument for this study. To sum it up research design allows the researcher to understand and strategize on how to explore factors which cannot be obtained through the use of qualitative and direct observations.

\section{Procedure for Data Analysis}

A descriptive statistic technique was employed in this study in order to analyse and administer data compiled from the questionnaire. The need for questionnaire survey method was due to the nature of the subject matter. The respondents were presented with questionnaire on how ethnicity plays role in political conflicts. The data was presented with percentages using tables for proper illustration.

\section{Descriptive Analysis of Data}

Data gathered for the study was presented and processed before it was analysed by adopting the content analysis method couple with frequency distribution and percentage tools used under descriptive statistics.

\section{DISCUSSION OF FINDINGS}

This work argued that the pattern of the grouping which later resulted in the amalgamation of the ethnic groups in 1914 was the beginning of ethnophobia (ethnic fears) in Nigeria; the introduction of regional governments which brought about strong regional sentiment among regional political leaders spearheaded ethnic politics with its resultant effect on sociopolitical and economic development. It is quite noticeable that ethnicity has affected and has eating deep into the fibre of every aspect of the governing process in Nigeria, it will be highly misleading for anybody to think that ethnicity is not harmful to Nigeria and its quest for sustainable political development; therefore, any socio-political and economic policy that will promote ethnic detestation could be calamitous for Nigeria federation. Significantly, ethnically divided societies tend to be divided in different ways. Given the case of Nigeria, divided societies can be politically fragmented into many contending groups. They can feature dominant majorities (e.g., Hausa/Fulani in the north, Yoruba in the West and Igbo in the East) or dominant minorities (e.g., the Tivs in the North Central and the Ijaws in the South West). The nature of the ethnic divide can thus have a significant influence on the way ethnic conflicts are manifested and consequently on the capacity of the political system to manage them (Reilly, 2000:163). One crucial factor influencing the relative success of the different states in implementing their ethnic strategy relates to the capability of the state to sufficiently and with good administrative and ideological capability implement.

Its ethnic management strategies in a reasonably competent way, without having a disruptive impact on the socio-political and economic system of the country (Brown, 1994) ethnic politics in Nigeria no doubt are a response to emotional needs for identity, security and political authority. It is, therefore, the quest for this political authority and power that has made some political leaders project themselves as the leader of this or that ethnic group, thereby dividing the country into hostile ethnic blocs. What this portends to mean is that if the threats with which members of in-group (the majority) or out-group (the minority) are faced would be reduced for political stability to thrive, Nigeria politics must be anchored on the need for the review of the constitutional and political structure of Nigeria to restore healthy political competition. As opposed to the existing outdated political mechanism imposed on Nigeria by the military under the 1999 Constitution of the Federal Republic of Nigeria as amended. If Nigeria must progress on her developmental journey; it is required that Nigeria has to develop political strategies based on structural and perceptual perspective. By structural it must involve political reforms at all level. From a perceptual perspective, it includes the elimination of misunderstanding brought about in the society in the name of ethnic politics. This, however, could be done when there is trust and close interaction with the contending parties; the ethnic groups and the state authority.

Meaning that; ethnic politics is significant to explain the prevalence of decay in Nigeria's political development; a problem that can be solved constitutionally while avoiding its lingering effects. Ethnic politics in Nigeria no doubt is underscored by the country's underdevelopment and weak economic growth. Thus, pointing to the need for a change in the country's approach to politics. Ethnic politics since independence has never favoured Nigeria, succinct to say that policymakers and politicians in the interest of political stability and egalitarian society must go all-out to build a conflict-free political system that will attract foreign investors, while enhancing economic development; apart from helping Nigeria to solidify its leadership positions as the largest economy in Africa. In multi-ethnic states such as the US, South Africa, Spain, Canada and Malaysia, where you come from is not a factor to becoming the leader but rather what you've got to contribute to the state's political and economic development.

Salawu and Hassan (2010) and Anifowose (2011) in a separate study concluded that the major contributor to ethnic conflict in Nigeria is what was described as constitutional factor. The focus of this line of argument is that constitutional 
developments in Nigeria, particularly the colonial constitutions, tended to engender ethnicism and hinder national integration of particular interest is Arthur Richard Constitution of 1946. This constitution established the first regional governments in Nigeria. Although the constitution achieved the integration of North and South in a common legislative council, it actually brought to force the concept of regionalism. Many political observers and commentators have observed that the 1946 constitution formed the beginning of the process of fragmentation along ethnic line in Nigeria. The Nigerian constitutional changes all along the colonial rule encouraged factionalism, which later resulted into ethnic nationalism. Richard Constitution built a pattern of political competition between the regions till the independence constitutional settlement.

\section{CONCLUSION}

It is concluded that Cultural Pluralism remains the bane of development in Nigeria and many African countries, because the various ethnic groups that make up the plurality of the national government have not risen beyond their ethnic peculiarities and selfish interests to the level of thinking of the good of the country as one, indivisible entity, poised to provide the goodies of nationalism our children and children's children. Until they rise beyond this ethnic sentiment, ethnic pluralism in Nigeria will continue to be a curse rather than a blessing.

Going by the findings ethnic politics sparks conflict to occur; this could be among ethnic groups or political parties. The second objective of the study revolves on whether struggle amongst ethnic groups has concrete effect on politics. From the study findings it could be concluded that struggle for political and economic power has no impact on political conflict amongst ethnic groups. This was in line with the third objective that is violence has no correlation with political instability. The current situation of Nigeria could be cited as an example. Violence in South South and North East does not reflect political instability in the country. Lastly political conflict is at it minimal level for the past few year in Nigeria but the impact of ethnicity on conflict remain intact and vivacious.

\section{RECOMMENDATIONS}

The study made the following recommendations:

1. Ethnicity being one of the major factors fuelling political conflict in Nigeria, the government and political parties should consider minority right in political appointment and include them in policy making process. This could be attained by meritorious rotation of ethnic groups in various governmental key positions. Hence, it will create sense of belonging to the nation.

2. There is need for the government to fully implement true federalism in order to avert hostility and conflict amongst ethnic groups. It has been manifested in the study that when human beings felt deprived of political, economic or social right, they easily adopt violence as a means of letting their voice be heard.

3. Fair resource allocation and equal provision of basic amenities amongst ethnic groups in Nigeria will aid to consort their relationships.

\section{Suggestions for Further Study}

1. Further study in this area should be done in other African countries. This will provide a crystal pictures of how ethnic methods of politics affects political development in Nigeria also the findings can then be compared with the finding of this study. Also a study on the effect of ethnic politics and its importance to Nigerian democracy should be extended so as to have a broader picture of the problems at hand.

\section{REFERENCES}

[1] Adejuyigbe, O. (1973). The Size of States and Political Stability in Nigeria. African Studies Review, 16(2), 157-182.

[2] Ademola, F. S. (2006). Theories of Social Conflict. In S. G. Best, Introduction to Peace and Conflict Studies in West Africa (pp. 5052). Ibadan: Spectrum.

[3] Adetiba, T. C. (2013). Ethnic Conflict in Nigeria: A Challenge to Inclusive Social and Political Development. PhD Thesis., University of Fort Hare, South Africa.

[4] Akpan, W. (2007). Ethnic Diversity and Conflict in Nigeria: Lessons from the Niger Delta Crisis. African Journal on Conflict Resolution, 7(2), 15-35.

[5] Alubo, O. (2009). Citizenship and Identity Politics in Nigeria. In Conference Proceedings on Citizenship and Identity Politics in Nigeria, Lagos: CLEEN Foundation, 1-4.

[6] Babangida, I. (2002). Ethnic Nationalities and Nigeria State. Excerpts from a Lecture delivered at National Institute for Policy and Strategic Studies, Kuru, Jos.

[7] Barr, A. \& Abena, O. (2002). Ethnic Fractionalization in an African Labour Market. Journal of Development Economics, (68), 355-379.

[8] Berman, J. B. (1998). Ethnicity, Patronage and the African State; The Politics of Uncivil Nationalism. African Affairs, (97), 305341.

[9] Blaikie, N. (2000). Designing Social Research: The Logic of Anticipation. Cambridge: Polity Press.

[10] Blanton, R., David, T. M. \& Brian, A. (2001). Colonial Style and Post-Colonial Ethnic Conflict in Africa. Journal of Peace Research, 38(4), 473-492.

[11] Broch-Due, V. (2005). Violence and belonging: Analytical reflections. In Broch-Due, V. (Ed). Violence and belonging: the quest for identity in post-colonial Africa (1-401) London: Routledge.

[12] Brown, D. (1994). The state and ethnic politics in Southeast Asia. London; Routledge.

[13] Brown, G. M. (2013). Nigerian Political System: An Analysis. International Journal of Humanities and Social Science, 3(10), 172-179.

[14] Buhaug, H. (2006). Relative Capability and Rebel Objective in Civil War. Journal of Peace Research, 43(6), 691-708.

[15] Chandra, K. (2012). Constructivist Theories of Ethnic Politics. New York; Oxford University Press.

[16] Collier, P. (1995). Nigeria: Economic policy reforms for growth and poverty reduction. London; Oxford University.

[17] Easterly, W. \& Levine, R. (1997). Africa's Growth Tragedy: Policies and Ethnic Divisions. Quarterly Journal of Economics, 112(4), 1203-1250. 
[18] Easterly, W. (2001). Can Institutions Resolve Ethnic Conflict? Economic Development and Cultural Change, (49), 687-706.

[19] Enwere, C. (2015). Conflict Studies: An Introduction. Enugu: Rossen.

[20] Erikson, T. H. (1991). Ethnicity versus Nationalism. Journal of Peace Research, 28(3), 263-278.

[21] Frank, R. \& Rainer, I. (2012). Does the Leader's Ethnicity Matter? Ethnic Favouritism, Education and Health in Sub-Saharan. Africa American Political Science Review, 106(2), 294-325.

[22] Geertz, C. (1973). The Interpretation of Cultures. New York; Basic Books.

[23] Gellner, E. (1983). Nations and Nationalism (reprint). Oxford; Blackwell

[24] Green, E. (2011). Explaining African Ethnic Diversity. Development Studies Institute. London School of Economics and Political Science

[25] Hashmi, S. R. \& Majeed, G. (2015). Politics of Ethnicity: A Theoretical Perspective. A Research Journal of South Asian Studies, 30(1), 319-331.

[26] Kelman, C. H. (2007). Social-Psychological Dimensions of International Conflict. In William, I. Z. (Ed). Peacemaking in International Conflict: Methods and Techniques (64-79). Washington, DC; United States Institute of Peace.

[27] Kimenyi, S. M. (2006). Ethnicity, Governance and the Provision of Public Goods. Journal of African Economies, 15(1), 62-99.

[28] Laitin, D. D. (1994). The Tower of Babel as a Coordination Game: Political Linguistics in Ghana. American Political Science Review, 88(3), 622-634

[29] Lake, D and Rothschild, D. (1996). Containing Fear:The Origins and Management of Ethnic Conflict. International Security, 46.

[30] Maclean, P. (1975). On the Evolution of Three Mentalities'. In C. \&. Arieti, New Dimensions in Psychiatry : A World View. New York: John Wiley \& Sons.

[31] Mamdani, M. (2002). Making Sense of Political Violence in Postcolonial Africa. Identity, Culture and Politics, 3(2), 1-24.

[32] Maslow, A. H. (1970). Motivation and personality. New York : Harper\& Row .

[33] Miguel, E. \& Mary, K. G. (2005). Ethnic Diversity, Social Sanctions, and Public Goods in Kenya. Journal of Public Economics, (89), 2325-2368.

[34] Milanovic, B. (2003). Is Inequality in Africa Really Different? Working Paper, No 3169, Development Research Group, World Bank.

[35] Mustapha, R. A. (2006). Ethnic Structure, Inequality and Governance of the Public Sector. United Nations Research Institute for Social Development Programme Paper Number 24.

[36] Naija Home based https://www.naijahomebased.com/geopoliticalzones-nigeria/ Accessed 17 July 2018.

[37] Nnoli, O. (1978). Ethnic politics in Nigeria. Enugu, Nigeria: Fourth Dimension Publishers.

[38] Northrup, T. A. (1989). "The Dynamic of Identity in Personal and Social Conflict. In L. Kriesberg, Intraceable Conflicts and TheirTransformation (pp. 55-56). New York: Syracuse University Press.

[39] Ogundipe, S. (October 13, 2017). Buhari asked us to focus on northern Nigeria - World Bank. The Punch Newspaper online. http://punchng.com/buhari-asked-us-tofocus-on-northern-nigeriawbank/ Accessed 13 October 2017.

[40] Olawale, S. (2018) Constitutional development in Nigeria from 1914 till date. Naijaques.com https://naijaquest.com/constitutional- development-in-nigeria-from-1914-till-date/ Accessed 8 April 2019.

[41] Olayode, K. (2016). Beyond Intractability: Ethnic Identity and Political Conflicts in Africa. International Journal of Humanities and Social Science, 6(6), 242-248.

[42] Onwe, O. J. (2019). Historicism of Ohanaeze Ndigbo political endorsements Guardian online. https://guardian.ng/politics/historicism-of-ohanaeze-ndigbopolitical-endorsements/ Accessed 17 February 2019.

[43] Osadolor, B. O. (1998). The Development of the Federal Idea and the Federal Framework, 1914-1960. In Amuwo, K. Agbaje, A. Suberu, T. R., \& Heraul, G. (Eds). Federalism and Political Restructuring in Nigeria (14-34). Ibadan: Spectrum Books Ltd.

[44] Osaghae, E. (2003). Explaining the changing patterns of ethnic politics in Nigeria. Nationalism and Ethnic Politics, 9(3), 54-73.

[45] Otite, O. (2002). Perspectives on National Integration in Multicultural Societies: A Nigerian View. In Isiugo, A. Charlie, U. Isamah, A. N. \& Adesina, O. J. (Eds). Currents and Perspectives in Sociology, Ibadan; Malthouse.

[46] Peel, J. D. Y. (1989). The cultural work of Yoruba ethnogenesis. In Tonkin, E. (Ed). History and Ethnicity (198 -200) London; Routledge.

[47] Posner, N. D. (2004). Measuring Ethnic Fractionalization in Africa. American Journal of Political Science, 48(4), 849-863.

[48] Reilly, B. (2000). Democracy, Ethnic Fragmentation, and Internal Conflict Confused Theories, Faulty Data, and the "Crucial Case" of Papua New Guinea. International Security, 25(3), 162-185.

[49] Ross, M. H. (1993). The Management of Conflict: Interpretations and Interest in Comparative Perspective. New Heaven: Yale UNiveristy Press .

[50] Rothbarth, D. \& Cherubin, R. (2009). Causation as a Core Concept in Conflict Analysis. In Sandole, J. D. Dennis, B. Sean, S. Sandole-Staroste, I. \& Senehi, J. (Eds). Handbook of Conflict Analysis and Resolution (9-70). London and New York; Routledge.

[51] Salawu, B. \& Hassan, A. O. (2011). Ethnic politics and its implications for the survival of democracy in Nigeria. Journal of Public Administration and Policy Research, 3(2), 28-33.

[52] Scandura, T. A. \& Williams, E. (2000). Research Methodology in Management the Academy of Management Journal, 43(6), 12481264.

[53] Shakir, M. (1982). On national integration. Social scientist, 10(4), 36-45.

[54] Snodgrass, D. R. (1995). Successful Economic Development in a Multi-Ethnic Society: The Malaysian Case (Cambridge, MA: Harvard Studies in International Development).

[55] Sriskandarajah, D. (2005). Development, Inequality and Ethnic Accommodation: Clues from Malaysia, Mauritius and Trinidad and Tobago, Oxford Development Studies, 33(1), 63-79.

[56] The Federal Republic of Nigeria. (2018). The 1999 Constitution http://www. icnl.org/research/library/files/Nigeria/constitution2.pdf Accessed October 222018.

[57] Wimmer, A., Cederman, L. \& Min, B. (2009). Ethnic Politics and Armed Conflict: A Configurational Analysis of a New Global Data Set. American Sociological Review, 74(2), 316-337.

[58] Worldometers. (2019). http://www.worldometers.info/worldpopulation/nigeria-popu -lation / Accessed 22 February 2019.

[59] Yin, R. K. (2003). Applications of case study research. Thousand Oaks, CA: Sage. 